\title{
Influence of E-Government Adoption and Political Stability - An Detailed review
}

\author{
${ }^{1}$ Derya Baran Canini and ${ }^{2}$ Woung Ying Yu \\ 1,2 Physical Science and Engineering Division, King Abdullah University of Science and Technology, \\ 1,2 Thuwal, Kingdom of Saudi Arabia \\ 1deryacaninibaran@gmail.com
}

\begin{abstract}
ArticleInfo
Journal of Enterprise Business Management (http://ijaict.com/jebm.html)

https://doi.org/10.46532/jebm.20200704

C2020 The Authors. Published by IJAICT India Publications.

Abstract - E-government is an emerging concept of new technology for the provision of services to the public resulting in increase in transparency and efficiency. Political stability means the stability and peaceful conditions of politics and government. Happiness is the state of mind in which a person is away from negativity and is full of satisfaction and well being. The basic purpose of this study is to check the impact of e-government and political stability on the level of happiness of people in the presence of two control variables, literacy rate and GDP growth. For research purpose, data is collected from ASEAN countries for 29 years from reliable resources. For research purpose, several techniques and tests are used such as panel unit root test, panel cointegration test, coefficient estimation test, Granger casualty test etc. As the consequence of these tests, the impact of e-government and political stability as well as the control variable, GDP growth on happiness level of people are accepted while the impact of a control variable, literacy rate are rejected. This study has several benefits and implications related to theoretical, practical and policy making benefits for the future researchers, citizens of a country and the government as well.
\end{abstract}

Received 04 March 2020; Revised form 14 April 2020; Accepted 26 May 2020; Available online 05 July 2020.

This is an open access article under the CC BY-NC-ND license. (http://creativecommons.org/licenses/by-nc-nd/4.0/)
Keywords - E-Government Adoption, Political Stability, Level of Happiness, ASEAN Countries

\section{Introduction}

Happiness is an emotion that is just felt and can also be used to depict various emotions that are positive in nature such as joy, pride, contentment etc. Many researchers have used the term of subjective well being of a person in order to describe or define happiness. [1] and [2] discussed the fact that the well being of a person is based on the level of satisfaction that person is experiencing in his life. Other than that, different emotions that are either positive or negative are also used to describe the well being and happiness of a particular person. A person feels happy and joyful when his life is satisfied and good in all aspects [3]. E-government can be understood as the use of technology and innovative practices in the services provided by government and information management systems in order to increase the transparency of different activities of government, effectiveness of that government etc. The basic aim of e-government adoption is to promote the growth and development of economy of the country. [4] argued that people of that country play an important part in this concept as they participate in different decision-making practices of government and can also collaborate with the government in order to bring various improvements in the services given by government using egovernment. Political stability can be defined in various terms [5]. A government where all the laws are obeyed in an effective way, where the government is out of any danger and where political situation is under control can be considered as politically stable government. A politically stable government enhances the market activities and improves the relationships with employees resulting in increase in productivity. In addition to that, a politically stable government also attracts many investments that are in the benefit of that country [6]. The country where there are no crimes and revolutionary attempts and where laws and regulations are carefully abided by are considered to be politically stable.

\begin{tabular}{l|l|r|r}
\hline No & \multicolumn{1}{|c|}{ Country } & \multicolumn{1}{|c}{ Average } & \multicolumn{1}{|c}{ Ranking } \\
\hline 1 & Philippines & -1.24 & 10 \\
\hline 2 & Myanmar & -1.08 & 9 \\
\hline 3 & Thailand & -0.76 & 8 \\
\hline 4 & Indonesia & -0.51 & 7 \\
\hline 5 & Malaysia & 0.16 & 6 \\
\hline 6 & Cambodia & 0.17 & 5 \\
\hline 7 & Vietnam & 0.31 & 4 \\
\hline 8 & Lao People's Democratic Republic & 0.43 & 3 \\
\hline 9 & Brunei Darussalam & 1.19 & 2 \\
\hline 10 & Singapore & 1.59 & 1
\end{tabular}

Fig 1: Political stability index of different ASEAN countries

C 2020 IJAICT India Publications (www.ijaict.com) 
Fig 1 represents the political stability index of various countries of ASEAN region. E-government adoption and political stability of a government result in the happiness of its citizens. But unfortunately in ASEAN countries, lack of activities related to e-government and political instability to some extent is resulting in depression and sadness factors in citizens. According to [7], other than ASEAN countries, other developing and underdeveloped countries are also facing the same issue among their citizens. If this situation is not solved in the very first attempt, it will have serious outcomes on the emotional and mental health of citizens of those countries. Therefore, it is crucial to promote e-government and political stability in order to get rid of this issue [8].

There are many researches that have studied different aspects of political stability and instability as well as egovernment and its applications [9]. In addition, different aspects of levels of happiness have also been studied. However, the effect of e-government and political stability on the levels of happiness has not been studied yet. Therefore, a research paper written by [10] has recommended studying this aspect. The most important aims of this study are as follows:

- To analyze the significant impact of E-Government adoption on levels of happiness in ASEAN countries

- To analyze the significant effect of Political Stability on levels of happiness in ASEAN countries

As ASEAN countries are growing economically day by day, much political instability is taking place there. The scope of this research revolves around the influence of egovernment adoption and political instability on the levels of happiness of people in ASEAN countries [11]. The significance of this study is that it will provide complete literature about the concepts of e-government, political stability and happiness factor in people and their impacts. In addition, it will assist the government of ASEAN countries to improve the political conditions of the country as well as to adopt e-government concept [12]. Moreover, it will also help the government to devise policies and regulations that support e-government and political stability aspects in order to increase the happiness levels of citizens.

\section{Literature Review}

\subsection{Hedonism Theory}

According to Hedonism theory, happiness is a feeling of a person. A happy person has all the positive emotions and is far away from the negative emotions. Happiness of a person can be seen through his physical appearance such as the shine in his eyes and smile on his face all the times [13]. Actually this theory explains what happiness actually is and when does a person feel happy. There are several reasons for a person being happy, the most important of which is the well being of that person. Actually the most important objective of a person in life is to remain happy. For this purpose, he is supposed to do anything within an appropriate limit that could make him happy [14]. As our study is based on the concept of egovernment and political stability and their respective impacts on happiness levels of people, therefore this theory can be used to study these concepts effectively. As egovernment and political stability play crucial role in the increase of well being of a person, and thus the increase in levels of happiness of a person, this theory can be effectively applied in our study.

\subsection{Impact of E-Government Adoption on Levels of Happiness}

E-government is basically the use of latest technologies and innovative tools in different services provided by government to the people [15]. This not only increases the transparency of the government services but also increases the efficiency and effectiveness of these services. The information and communication technologies used in the e-government concept leads towards the better relationships between government and people of that country. [16] discussed its reason in such a way that people have more easy access to government services and they can make better use of them in their lives. As a result, citizens of that country collaborate with the government in its various activities so that the government may improve and grow. In order to improve the well being of its people, government tries to know about the needs and wants of its citizens [17]. In addition, government also tries to indicate various aspects that can make the quality of life better of its people as well as the government. A union of various emirates that is collectively called as United Arab Emirates UAE is one of the richest countries due to its widespread and successful economy in the world. [18] explained the fact that the economic growth and development of UAE is actually because of the best usage and management of its oil reserves by its government. They have made a lot of innovations and technological advancements in almost every sector of that country, which results in the attraction of more and more tourists and people from all over the world in order to visit that country [19]. This also has added in the economic development and growth of that country. They have also moved towards e-government because they are very stable financially and can afford all the expenses that are related to the innovative practices and technologies in the concept of e-government. It is the goal of their government to provide these latest services related to egovernment to their citizens every time they need it and thus improve the quality of lives of their people and their well being. [20] concluded that this ultimately will increase the happiness levels of their citizens. In addition to that, the government of UAE has also created a ministry known as the ministry of happiness. The basic objective of this ministry is to identify and create different projects of innovative and technological nature that may increase the life quality and thus the happiness levels of their citizens [21]. From this discussion, we can conclude that e-government adoption has significant impact on the happiness of the citizens of any country. We can generate the following hypothesis:

H 1: E-Government Adoption has significant impact on Levels of Happiness in ASEAN Countries

(C) 2020 IJAICT India Publications (www.ijaict.com) 


\subsection{Impact of Political Stability on Levels of Happiness}

Any county will be called stable if the laws and regulations are abided by the people, the government is working without any pressure and threat of being removed and the political conditions of the government are stable [22]. These are the most important and basic aspects of political stability. As we know that government has strong connection and relationship with its citizens, its political conditions also affect the people in one way or the other. When there are proper laws and regulations for every aspect in the country that makes the country peaceful and thus increases the satisfaction and happiness levels of its citizens. In the same way, [23] argued that if the government is stable and working independently without any pressure, it will ultimately develop new ideas involving technology and other improvement aspects that will be in the better interest of its citizens and will improve their life quality. This not only increases their well being but also the levels of happiness in them. Studies conducted by [24] and [25] have shown that if a government is politically stable and there are no non-peaceful events taking place in the country, it will improve the satisfaction levels of its people and they feel contented while living there. So overall, people living in a peaceful country are happier as compared to the other countries. If the people are happier, they also take part in making the government more stable and also contribute towards the growth and development of their country [26]. From the above discussion we can conclude that political stability of government of a country has significant impact on the levels of happiness of its citizens. We can generate the following hypothesis:

H 2: Political Stability has significant impact on Levels of Happiness in ASEAN Countries.

\section{Methodology}

\subsection{Data}

Data collection or data gathering is one of the most important tasks or steps of a research process as it is the data, which becomes the base of all the results of researchers. In order to conduct an accurate and reliable research it is very necessary to collect data from the most reliable source available [27]. In this regard, the author has collected data about the variables of this study that include e-government adoption, political stability, and happiness along with two control variables i.e. GDP growth and literacy rate. The data collected about these variables was comprised of 29 years and was collected from the most reliable sources such as World Bank, World development indicators, E-government development index etc. so that a healthy research with effective results can be conducted. The data was collected from all the countries of ASEAN region [28].

\subsection{Model Specification}

It is very evident that there are two independent variables of this study i.e. e-government adoption and political stability along with a single dependent variable i.e. level of happiness. In addition, two control variables have been used in the study which may affect the dependent variable. These control variables include literacy rate and GDP growth. The main aim of this study is to check the impact of independent variables on dependent variables in the presence of control variables [29]. All the variables included in this study have their own importance and measurement units. These measurement units are discussed here in detail. The first independent variable, e-government adoption (EGOV) is measured as the percentage of individuals adopting the concept of e-government. The second independent variable, political stability (POL) is measured in form of a political stability index. The dependent variable of this study, happiness (HAP) is measured as satisfaction with life scale. The first control variable, GDP growth (GDP) is measured in terms of change in GDP over the years. The other control variable, literacy rate (LIT) is measured in terms of the percentage of people that are literate in a country. All these variables have their own importance in the study and they can be used to derive the regression equation for this study. This regression equation is given below:

$$
H A P_{i t}=\alpha+\beta_{1} E G O V_{i t}+\beta_{2} P O L_{i t}+\beta_{3} G D P_{i t}+\beta_{4} L I T_{i t}+
$$

Where, HAP is level of happiness, EGOV is egovernment adoption, POL is political stability, GDP is GDP growth, LIT is literacy rate, $\alpha$ is used to denote constant, $\mathrm{i}$ shows cross sectional data, $t$ represents time series data and cit is a term that represents the error.

\section{Estimation Procedure}

After the collection of data, the next most important step is to critically evaluate and test it for research purposes. In order to serve the aim of the study and to confirm the final status of hypotheses produced in the study, various techniques and approaches have been applied on the data. These approaches include panel unit root test, cointegration test, coefficient estimation test and Granger casualty test [30]. The results derived from these techniques and approaches result in the evaluation of various hypotheses of the study and finalize their acceptance or rejection status. All the tests and approaches along with their benefits and general equations have been discussed in this section.

\subsection{Panel Unit Root Test}

The basic step in the evaluation of data is to determine the fact whether the data is stationary or not. For this purpose, the test employed in this study is panel unit root test, which is very much more beneficial from the conventional based on its more accurate and reliable results. Panel unit root tests consist of two important tests namely LLC and IPS. Both of them are actually the extensions or modification of DickeyFuller unit root tests as elaborated by [31]. The individual benefit of IPS unit root test is that it provides a heterogeneous results of autoregressive process run for the cross sectional data. Conversely, LLC provides homogeneous autoregressive results in the same scenario. The collective benefits of these tests include the provision of standard normal distribution of data as well as the identification of stationary or non stationary state of the concerned data. In addition to standard

(C) 2020 IJAICT India Publications (www.ijaict.com) 
normal distribution, these tests also provide more accurate and exact values for the result. This is due to the fact that variation and non stationarity of data increases the power of panel unit root tests as compared to the old and traditional unit root tests, which provide approximated results. The variation in the data must not only be confined to the variation in the observation, because it also involves the numbers or values of the data collected. The integration among variables can also be evaluated with the help of this test. The author has applied LLC test in this study whose equation is provided below:

$$
\Delta y_{i, t}=a_{i}+\rho y_{i, t}-1+\sum_{J=1}^{p i} a_{J} \Delta y_{i, t-J}+\varepsilon_{i, t}
$$

\subsection{Panel Cointegration Test}

Once the integration and stationery and non stationary state of the data is confirmed, the research process leads towards the next step, which is to know whether the variables are in cointegration or not. The stationarity of data has significant role in this regard. The non stationary data having certain variations in the data shifts to the stationary data in first difference series. For this purpose, the test employed in this study is called panel cointegration test. This is not a single term instead it consists of two types of tests i.e. Kao and Pedroni, which are the extracts of Engle-Granger cointegration tests. These cointegration tests measure the statistic values of two approaches i.e. "within dimension" and "between dimension" approach. The within approach has four types of statistics in this regard, which include panel $\mathrm{v}$ statistic, panel rho statistic, panel PP statistic (non parametric) and panel ADF statistic (parametric). Contrarily, between dimension approach has three values of statistics i.e. group rho statistic, group PP statistic (nonparametric) and group ADF statistic (parametric). In this particular study, the author has used Kao approach to study cointegration between variables. The general equation of this test is given as: $y_{i, t}=\alpha_{i}+\delta_{i, t}+\beta_{1} X_{1, i, t}+\beta_{2} X_{2, i, t}+\cdots+\beta_{n} X_{n, i, t}+\varepsilon_{i, t}$ (3)

\subsection{Coefficient Estimation Test}

After having evaluated the integration and cointegration of variables included in the study i.e. e-government adoption, political stability, level of happiness, GDP growth, literacy rate, the research process will now lead towards the estimation of coefficients of these variables. Two techniques FMOLS and DOLS are generally in use for this purpose. According to [32], FMOLS is actually a non parametric technique while DOLS is a parametric technique used for this purpose. Both these techniques are the derivatives of old OLS technique that did not provide authentic results. In this particular study, the technique used by the author is DOLS, for which the general equation is presented below:

$$
\begin{aligned}
& \hat{\beta}_{F M=}\left(\sum_{i=1}^{N} \sum_{t=1}^{T}\left(x_{i, t}-\bar{x}_{i}\right)^{2}\right)^{-1} \sum_{i=1}^{N}\left(\sum _ { t = 1 } ^ { T } \left(x_{i, t}-\right.\right. \\
& \left.\left.\bar{x}_{i}\right) H A P_{i, t}-T \hat{\delta}_{\varepsilon u}\right)
\end{aligned}
$$

Here $H A P_{i, t}$ is the transformed variable of level of happiness

\subsection{Granger Casualty Test}

After finding out the cointegration between several variables of the study, next thing is to identify any casual relationships existing among them. [33] illustrated that these casual relationships can be probed by using Dumitrescu and Hurlin Granger casualty test, whose equations are given as follows:

$$
\begin{aligned}
& x_{t}=\sum_{i=1}^{\infty} a_{i} x(t-i)+c_{1}+\mu_{1(t)} \\
& x_{t}=\sum_{i=1}^{\infty} a_{i} x(t-i)+\sum_{j=1}^{\infty} b_{j} y(t-j)+c_{2}+\mu_{2(t)}
\end{aligned}
$$

(6)

\section{Empirical Analysis}

\subsection{Results of Unit Root Test}

The author has used panel unit root test in order to check the integration and stationery and non stationary state of the data related to various variables of this study. This test has shown the results given in table 1 . This table depicts that the null hypothesis of the data of level series cannot be rejected and thus the data is considered to be stationary. In addition, the variables are integrated of order zero. After level series, the results of the same test for first difference series showed that the "null hypothesis" can be rejected and thus the data will be considered as non stationary. This rejection of null hypothesis has significance levels of both one percent and five percent randomly for all the variables. Along with this, the variables are integrated with order one due to no unit roots at first difference series. In short, we can say that the data at level series is stationary and has unit root while the data at first difference series is non stationary and without unit root.

Table 1: Panel Unit Root Test

\begin{tabular}{lll}
\hline \multicolumn{1}{c}{ Variable } & Level & First Difference \\
\hline HAP & $-1.73655(0.1735)$ & $-3.68316^{* *}(0.0014)$ \\
EGOV & $-2.81365(0.3816)$ & $-2.18367^{*}(0.0007)$ \\
POL & $-2.36815(0.7318)$ & $-1.17752^{* *}(0.0063)$ \\
GDP & $-1.17383(0.3618)$ & $-2.56371 *(0.0032)$ \\
LIT & $-0.83165(0.3151)$ & $-0.71358^{* *}(0.0046)$ \\
\hline
\end{tabular}

(C) 2020 IJAICT India Publications (www.ijaict.com) 


\subsection{Results of Panel Cointegration Test}

After knowing the integration of various variables of this study, the next test in the research process is to perform panel cointegration test. This test is actually performed in order to check the cointegration among different variables as well as to check the steadiness of these variables. In this study, the author has used the Kao test, the results of which are given in table 2 . These results show that in the within dimension section in the table, three out four statistic values have been rejected (panel rho statistic, panel PP statistic, panel ADF statistic) with significance levels of one for each statistic. Other than that, in between dimension section, two out of three statistic values have been rejected (group rho statistic, group ADF statistic) with the significance levels of five for both values. Considering overall values, five out of seven statistic values have not accepted the null hypothesis. As parametric and non parametric statistic values are very important in this regard, therefore the conclusion can be drawn that the variables are in cointegration with each other.

Table 1: Panel Cointegration Test

\begin{tabular}{clll}
\hline \multicolumn{1}{c}{ Dimension } & Tests & Statistics & T-value \\
\hline \multirow{2}{*}{ Within Dimension } & Panel v statistic & -2.28642 & -1.61813 \\
& Panel rho statistic & $-1.86428^{*}$ & -3.38161 \\
& Panel PP statistic & $-0.82463^{*}$ & -2.91373 \\
& Panel ADF statistic & $-1.71361^{*}$ & -2.37161 \\
\hline \multirow{2}{*}{ Between Dimension } & Group rho statistic & $-2.38136^{* *}$ & -3.39136 \\
& Group PP statistic & -1.57211 & -1.46861 \\
& Group ADF statistic & $-2.36816^{* *}$ & -3.17384 \\
\hline
\end{tabular}

\subsection{Coefficient Estimation Test}

Till now, the cointegration of the variables has been identified by the author. The next step in this process is to estimate and calculate the coefficients of several variables of this study. For this purpose, coefficient estimation test DOLS has been performed by the author for both pooled and grouped versions. The results of this DOLS test are presented in the table 3 given below. The table shows that the coefficients of e-government are 0.826 and 1.257 for pooled and grouped versions respectively. The significance levels of these values are one and five percent respectively. This shows that e-government adoption has significant impact on level of happiness of people. The coefficients of the other independent variable, political stability are 1.256 and 1.428 for pooled and grouped versions respectively with significance levels of five and one percent respectively. This result shows that political stability also has the significant impact on level of happiness of people. Other than independent variables, the result of coefficient estimation for first variable, GDP growth shows significant impact in our study. However, the other control variable, literacy rate does not show significant impact in this study. Overall, we can say the the two major hypotheses of this study are accepted along with the control variable, GDP growth. The impact of the other control variable cannot be accepted.

Table 2: Coefficient Estimation Test

\begin{tabular}{lll}
\hline Variables & Pooled & Grouped \\
\hline EGOV & $0.826^{*}(2.173)$ & $1.357^{* *}(2.294)$ \\
POL & $1.256^{* *}(3.347)$ & $1.428^{*}(2.408)$ \\
GDP & $0.725^{*}(3.508)$ & $-0.013^{*}(-2.052)$ \\
LIT & $-1.381(-0.792)$ & $1.311(0.863)$ \\
R-Squared Adj. & 0.836 & 0.793
\end{tabular}

\subsection{Results of Granger Casualty Test}

As the integration and cointegration have been identified between the variables of out study, the next and final step in this regard is to find any existing casual relationships between variables of this study i.e. e-government adoption, political stability, level of happiness, literacy rate and GDP growth. For this purpose, the author has used Granger casualty test in this study. The results of this study are shown in the table 4 . The table shows that various variables

(C) 2020 IJAICT India Publications (www.ijaict.com) 
have certain casual relationships among themselves. These relationships include the following; happiness level and political stability, e-government and happiness level, egovernment and GDP growth, political stability and happiness level, political stability and e-government, GDP growth and happiness level, GDP growth and political stability and finally literacy rate and GDP growth. All the above-mentioned variables have certain casual relationships among them.

Table 3: Granger Casualty Test

\begin{tabular}{llllll}
\hline & HAP & EGOV & POL & GDP & LIT \\
\hline HAP & - & 0.6381 & $0.1375^{*}$ & 0.8161 & 0.0238 \\
EGOV & $0.1973^{*}$ & - & 0.3862 & $0.3861^{*}$ & 0.3571 \\
POL & $0.3736^{*}$ & $0.3818^{*}$ & - & 0.9163 & 0.3711 \\
GDP & $0.9284^{* *}$ & 0.4681 & $0.8246^{*}$ & - & $0.8367^{*}$ \\
LIT & 0.8163 & 0.3811 & 0.0722 & $0.4932^{*}$ & -
\end{tabular}

\section{Discussion and Conclusion}

\subsection{Discussion}

The main purpose of this study was to check the impact of egovernment adoption and political stability on level of happiness in the presence of control variables i.e. literacy rate and GDP growth of a country. Various hypothesis were produced and tested by using various techniques and tools and were either accepted or rejected as a result. The first hypothesis of this study was that e-government adoption has significant impact on level of happiness of people in ASEAN countries. This hypothesis was tested by using different approaches and was considered to be accepted. The reason behind is that the use of e-government makes it easier for the people to use government services, resulting in increase of satisfaction and thus happiness. A past study by [34] has also shown the same result in this scenario. The next hypothesis was that political stability has significant impact on level of happiness in ASEAN countries. This hypothesis was also tested in the same way using different approaches, as a result of which it was also accepted. Political stability of a country increases the satisfaction level of people of a country. The same result has been shown by another past study conducted by [35]. After these major hypotheses, there were two control variables i.e. literacy rate and GDP growth. The impact of literacy rate has been rejected in this study after applying different tests and techniques. This is the same result shown by the other researchers too such as [36]. The impact of last control variable GDP growth has been accepted as a result of different tests and approaches because greater GDP results in the increased well being of people of a country. This is the same approach shown by another research [37].

\subsection{Conclusion}

E-government shows the concept of new technology usage in various government services and information management aspects to increase efficiency and effectiveness of these services and information provision and management practices to its citizens. Political stability means the peaceful conditions in the politics and governmental affairs of the country. Happiness is a state of mind in which a person is away from all the negative thoughts and tensions of life, surrounded by a complete atmosphere of positivity. The basic aim of this study was to check the impact of e-government and political stability on the level of happiness of people in the presence of two control variables, literacy rate and GDP growth. Data was collected from ASEAN countries for 29 years about the concerned variables. In order to evaluate the data collected, several techniques and approaches were used such as panel unit root test, cointegration test, coefficient estimation test, Granger casualty test etc. As a result of these tests, the impact of e-government and political stability along with a control variable, GDP growth on happiness level of people has been accepted while the impact of a control variable, literacy rate has been rejected. This study has several benefits and implications related to theoretical and practical aspects as well as policy making by the government.

\subsubsection{Implications}

This study has several theoretical, practical and policy making benefits and implications. This study will provide detailed literature and information about the important aspects of e-government and political stability and their impact on level of happiness. In addition to this, this research is also supposed to provide assistance to the government to make the concept of e-government better in sense of usage and to stabilize the political conditions in the country. This study will also provide help to the governments in making policies and regulations favorable for improving the usage of e-government and stabilizing the political conditions in the country. This will not only increase the happiness level of people. It will also increase the productivity, growth and development of the country and its economy.

(C) 2020 IJAICT India Publications (www.ijaict.com) 


\subsubsection{Limitations and Future Indications}

As this is not a full-fledged study, therefore there are various limitations of this study. The most important limitations include smaller size of sample, focus only on countries of ASEAN region, usage of only a few selected approaches and techniques for evaluating the collected data, focus only on selected variables only etc. These limitations and loopholes can be fulfilled by the future researchers. In this regard, the future researchers can increase the size of the samples for providing a broader view and conducting an effective and reliable research. In addition, they can also focus on some other regions or sets of countries of the world in regard of data collection. In future researches, authors can use more approaches and techniques other than panel unit root test, panel cointegration test, coefficient estimation test and Granger casualty test etc. in order to evaluate the hypotheses. Finally, future researchers can also use variables other than those used in this study.

\section{References}

[1]. Abu-Shanab, E. A. E-government familiarity influence on Jordanians' perceptions.Telematics and Informatics, 34(1), 103$113,2017$.

[2]. Al-Hujran, O., Al-Debei, M. M., Chatfield, A., \& Migdadi, M. The imperative of influencing citizen attitude toward egovernment adoption and use. Computers in Human Behavior, 53, 189-203,2015.

[3]. Al-Mulali, U., \& Ozturk, I.The effect of energy consumption, urbanization, trade openness, industrial output, and the political stability on the environmental degradation in the MENA (Middle East and North African) region. Energy, 84, 382-389,2015.

[4]. Al-Seheel, A. Y., \& Noor, N. M. Effects of an Islamic-based gratitude strategy on Muslim students' level of happiness. Mental Health, Religion \& Culture, 19(7), 686-703,2016.

[5]. Alam, M. B. e-Government in India Public Administration in South Asia (pp. 173-192): Routledge,2017.

[6]. Anthopoulos, L., Reddick, C. G., Giannakidou, I., \& Mavridis, N. Why e-government projects fail? An analysis of the Healthcare. gov website. Government Information Quarterly, 33(1), 161$173,2016$.

[7]. Arab, M., Rafiei, H., Safarizadeh, M. H., Ahmadi, J. S., \& Safarizadeh, M. M. Stress, anxiety and depression among medical university students and its relationship with their level of happiness. J Nurs Health Sci, 5, 44-47,2016.

[8]. Arendsen, R., Peters, O., Ter Hedde, M., \& Van Dijk, J. Does egovernment reduce the administrative burden of businesses? An assessment of business-to-government systems usage in the Netherlands. Government Information Quarterly, 31(1), 160$169,2014$.

[9]. Bai, Y., \& Jia, R. Elite recruitment and political stability: the impact of the abolition of china's civil service exam. Econometrica, 84(2), 677-733,2016.

[10]. Buffat, A. Street-level bureaucracy and e-government. Public Management Review, 17(1), 149-161,2015.

[11]. Camp, R. A. Mexico's political stability: the next five years: Routledge, 2019.

[12]. Caselli, F., \& Tesei, A. Resource windfalls, political regimes, and political stability. Review of Economics and Statistics, 98(3), $573-590,2016$

[13]. Cordero, J. M., Salinas-Jiménez, J., \& Salinas-Jiménez, M. M. Exploring factors affecting the level of happiness across countries: A conditional robust nonparametric frontier analysis. European Journal of Operational Research, 256(2), 663-672,2017.

[14]. Cox, G. W., \& Weingast, B. R. Executive constraint, political stability, and economic growth. Comparative Political Studies, 51(3), 279-303,2018.
[15]. Drakopoulos, S. A. Values and economic theory: The case of hedonism: Avebury Aldershot,1991.

[16]. Flory, T. Judge and Jury in Imperial Brazil, 1808-1871: Social Control and Political Stability in the New State (Vol. 53): University of Texas Press,2015.

[17]. Güler, M., Mukul, E., \& Büyüközkan, G. Analysis of egovernment strategies with hesitant fuzzy linguistic multi-criteria decision making techniques. Paper presented at the International Conference on Intelligent and Fuzzy Systems,2019.

[18]. Hardgrave, R. L. India under pressure: Prospects for political stability: Routledge, 2019.

[19]. Huang, J., Wu, S., \& Deng, S. Relative income, relative assets, and happiness in urban China. Social indicators research, 126(3), 971-985,2016.

[20]. Jiménez-Rodríguez*, R., \& Sánchez, M. Oil price shocks and real GDP growth: empirical evidence for some OECD countries. Applied economics, 37(2), 201-228,2005.

[21]. Köhler, A. Employee Happiness in an Activity-based Work Environment: An Explorative Study of Different Interventions to Understand the Interrelation between Acoustic Privacy and Personalisation and the Employees' Level of Happiness, 2019.

[22]. Kurfalı, M., Arifoğlu, A., Tokdemir, G., \& Paçin, Y. Adoption of e-government services in Turkey. Computers in Human Behavior, $66,168-178,2017$.

[23]. Okong'o, K., \& Kyobe, M. E-Governance as an Alternative Antecedent to a Lean Public Sector: Theory and Evidence. The African Journal of Information Systems, 11(1), 4,2019.

[24]. Oswald, A. J., Proto, E., \& Sgroi, D. Happiness and productivity. Journal of Labor Economics, 33(4), 789-822,2015.

[25]. Padela, A. I., \& Heisler, M. The association of perceived abuse and discrimination after September 11, 2001, with psychological distress, level of happiness, and health status among Arab Americans. American journal of public health, 100(2), 284291,2010.

[26]. Pedroni, P. Critical values for cointegration tests in heterogeneous panels with multiple regressors. Oxford Bulletin of Economics and statistics, 61(S1), 653-670,1999.

[27]. Pedroni, P. Fully modified OLS for heterogeneous cointegrated panels Nonstationary panels, panel cointegration, and dynamic panels (pp. 93-130): Emerald Group Publishing Limited,2001a.

[28]. Pedroni, P. Purchasing power parity tests in cointegrated panels. Review of Economics and Statistics, 83(4), 727-731,2001b.

[29]. Pedroni, P. Panel cointegration: asymptotic and finite sample properties of pooled time series tests with an application to the PPP hypothesis. Econometric theory, 20(3), 597-625,2004.

[30]. Sá, F., Rocha, Á., \& Cota, M. P. Potential dimensions for a local e-Government services quality model. Telematics and Informatics, 33(2), 270-276,2016.

[31]. Schnoll, H. J. E-Government: Information, Technology, and Transformation: Information, Technology, and Transformation: Routledge, 2015.

[32]. Soper, K. Alternative hedonism, cultural theory and the role of aesthetic revisioning Cultural Studies and Anti-Consumerism (pp. 59-79): Routledge, 2014.

[33]. Steckel, R. H. Height and per capita income. Historical Methods: A Journal of Quantitative and Interdisciplinary History, 16(1), 1$7,1983$.

[34]. Tokuda, Y., Fujii, S., \& Inoguchi, T. Individual and CountryLevel Effects of Social Trust on Happiness: The Asia Barometer Survey Trust with Asian Characteristics (pp. 123-139): Springer,2017.

[35]. Uchida, Y., \& Oishi, S. The happiness of individuals and the collective. Japanese Psychological Research, 58(1), 125$141,2016$.

[36]. Venkatesh, V., Thong, J. Y., Chan, F. K., \& Hu, P. J. Managing citizens' uncertainty in e-government services: The mediating and moderating roles of transparency and trust. Information Systems Research, 27(1), 87-111,2016.

[37]. Von Vorys, K. Democracy without consensus: Communalism and political stability in Malaysia: Princeton University Press,2015.

(C) 2020 IJAICT India Publications (www.ijaict.com) 